\title{
ПРОБЛЕМА КАДРОВОГО ЗАБЕЗПЕЧЕННЯ УПРАВЛІННЯ ПРИРОДОКОРИСТУВАННЯМ І ПРИРОДООХОРОННОЮ ДІЯЛЬНІСТЮ
}

\footnotetext{
У статті розглянуто питання необхідності забезпечення еколого-правової підготовки фахівиів з управління природокористуванням й природоохоронною діяльністю; пропонується концепџія магістерської програми підготовки професіоналів зі спеціальності 8.18010005 - «Екологічна політика і право» у Національному університеті біоресурсів $i$ природокористування України.

Ключові слова: еколого-правова підготовка, управління природокористуванням й природоохоронною діяльністю.

В статье рассмотрены вопросы необходимости обеспечения эколого-правовой подготовки специалистов по управлению природопользованием и природоохранной деятельностью; предлагается кониепиия магистерской программы подготовки профессионалов по специальности 8.18010005 - «Экологическая политика и право» в Национальном университете биоресурсов и природопользования Украины.

Ключевые слова: эколого-правовая подготовка, управления природопользованием и природоохранной деятельностью.
}

The article deals with the need for environmental and legal training on environmental management and environmental management, offers the master's programs for professionals in specialty 8.18010005 - «Environmental Policy and Law»at the National University of Life and Environmental Sciences of Ukraine.

Key words: Environmental Law training, environmental management and environmental activities.

Екологічна криза спонукала до визначення нової парадигми - екологічної і водночас культурної системи цінностей, понять і сприймань, що формують нове бачення реальності, засноване на гармонізації взаємин людини, суспільства й природи [1]. Для України, яка, власне, вже опинилася на межі виснаження природного потенціалу, сталий розвиток доцільно розглядати як такий, де природа виступає домінантою життя, а не ресурсом економічного зростання. Саме тому багатофакторний процес управління природоохоронною діяльністю відповідно до природних законів життєдіяльності суспільства має сприйматися як єдиний надійний засіб досягнення сталості його розвитку 3 пріоритетами збалансованого застосування технологічних i біотичних механізмів регулювання процесу гармонізації життя, регіональним моделюванням шляхів і способів практичного досягнення гармонії та переходу до сталого розвитку.

Ефективне управління природокористуванням й природоохоронною діяльністю в кожній із галузей народного господарства неможливе без знання його наукових основ. Для творчого розвитку сформованості висококваліфікованих фахівців необхідним $є$ вивчення наукових основ екологоправової теорії управління природокористуванням й природоохоронною діяльністю в цілому. Складний період інституційного реформування має важливе державне значення, оскільки покликаний допомогти у вирішенні життєво важливих соціально-економічних, еколого-економічних проблем майбутнім спеціалістам народного господарства.

В останнє десятиліття у вітчизняній науковій літературі було приділено значну увагу проблемам і перспективам еколого-правового регулювання економічної діяльності (Л. Горбач, В. Кострицький, Ю. Кулаковський, М. Шульга, В. Мунтян, В. Ситнік, В. Андрейцев, Ю. Шемшученко, С. Кравченко, А. Гетьман, Л. Здоровко, В. Мартиненко, Н. Малишева, О. Лазор, С. Разметаєва, Г. Мороз, Б. Бредіхіна, М. Бринчук, М. Хвесик), екологічним основам раціонального природокористування та впровадженню засад управління природоохоронною діяльністю (В. Гетьман, Л. Кожушко, Л. Мельник， В. Навроцький， Ю. Саталкін， Т. Сафранов， П. Скрипчук， І. Солошич， Т. Трушина, М. Шапочка, В. Шевчук, В. Шмандій), розвитку екологічної освіти і культури (Г. Білявський, В. Горова, О. Захлебний, І. Звєрев, М. Дробноход, В. Добровольський, В. Максимова, М. Мойсєєв, А. Мягкова, В. Некос, Н. Рідей, О. Созінов, С. Степаненко, І. Суравегін).

Актуальність теми дослідження зумовлена суперечностями між: вимогами суспільства до висококваліфікованих фахівців 3 еколого-правовою підготовкою управління природоохоронною діяльністю в Україні та відсутністю науково-методичного забезпечення їхньої підготовки; потребами державних органів влади і місцевого самоврядування у мобільних фахівцях 3 управління природоохоронною діяльністю, які досконало володіють сучасними методами і засобами реалізації професійної діяльності та невідповідністю (або недосконалістю) процедур дотримання законодавчих і нормативно-правових актів регулювання цієї сфери; підвищенням якості професійно орієнтованої еколого-правової підготовки фахівців 3 управління природоохоронною діяльністю у вищих навчальних закладах і відсутністю теоретичних аспектів їх розробки.

Mema cmammi - дослідити сутність практики еколого-правової підготовки. Ї̈̈ метою в контексті забезпечення екологічної освіти для сталого розвитку є організація державних і комерційних систем освіти різних рівнів (міжнародного, національного, регіонального), що передбачають безперервне екологічне навчання та просвіту для розвитку екологічної культури і основ наукових екологічних знань широких верств населення, наукового екологічного світогляду i професійних навичок 
заощадливого природокористування, ресурсозбереження, біовідтворення та формування екологічної безпеки навколишнього середовища та безпеки життєдіяльності людини у фахівців виробничої (промислової, аграрної) і невиробничої діяльності [2; 3; 4].

Для реалізації поставленої мети необхідно розвивати екологічну, правову й економічну підготовку, перепідготовку, стажування науково-педагогічних співробітників з питань екологічно збалансованого соціально-економічного розвитку; систематично проводити еколого-правову підготовку керівників та адміністраторів виробничої діяльності, галузей економіки для підвищення рівня їх професійної компетенції при запровадженні систем екологічного управління і дотриманні природоохоронного законодавства.

Постановою Кабінету Міністрів України «Про затвердження переліку спеціальностей, за якими здійснюється підготовка фахівців у вищих навчальних закладах за освітньо-кваліфікаційними рівнями спеціаліста і магістра» (2010) [5] розширено перелік спеціальностей галузі знань «1801 Специфічні категорії» - спеціальності, за якими здійснюється підготовка професіоналів на основі базової або повної вищої освіти за переліком галузей знань, напрямів підготовки і спеціальностей, який визначається центральними органами виконавчої влади за погодженням із МОН молодь спорту України.

Необхідність розроблення, впровадження і розвитку екологічних освітніх екологічних програм еколого-правової підготовки магістрів спеціальності 8.18010005 - «Екологічна політика і право» обумовлена прагненням інтеграції України з Європейським Союзом, входженням до Світової організації торгівлі і сприйнятті її світовою спільнотою як держави, яка не лише демонструє схильність керівництва до екологічних пріоритетів, а й формує багаторівневий освітній простір для сталого розвитку, забезпечує підготовку екологічно-компетентних професіоналів-управлінців у різних освітніх напрямах, здатних дотримуватись вимог цивілізованого бізнесу, сприяти відповідності якості продукції та процесу ії виробництва міжнародним стандартам без шкоди для довкілля і життю людей.

У зв'язку з цим постає питання необхідності ліцензування освітньої діяльності вищих навчальних закладів освіти (далі - ВНЗ) з підготовки фахівців освітньо-кваліфікаційного рівня «Магістр» зі спеціальностей галузі знань 1801 - «Специфічні категорії». Для цього їм необхідно створити систему заходів щодо досягнення якісно нового рівня у підготовці таких фахівців, забезпечити умови для задоволення потреб кон'юнктури ринку (роботодавця) та особистості відповідно до компетенції, здібностей, нахилів й інтересів людини, що може бути досягнуто при впровадженні державних стандартів вищої освіти (адаптованих до вимог Болонської конвенції), розширенні мобільності освіти й підвищенні конкурентоздатності випускників на ринку праці.

Національний центр екологічної освіти і науки. Одним із провідних закладів освіти, науки і культури в Україні, що здатен забезпечити еколого-правову підготовку професіоналів, $\epsilon$ Національний університет біоресурсів і природокористування України (далі - НУБіП України). Історія НУБіП України бере свій початок від сільськогосподарського відділення, яке було відкрите 30 вересня 1898 p. у Київському політехнічному інституті і трансформувалось у 1918 р. у сільськогосподарський (агрономічний) факультет. На базі цього факультету в 1922 р. у структурі КПІ було створено Київський сільськогосподарський інститут, який з 1923 р. став самостійним вищим навчальним закладом. У 1954 р. Київський сільськогосподарський інститут було об'єднано 3 Українським лісогосподарським інститутом в єдиний навчальний заклад - Українську ордена Трудового Червоного прапора сільськогосподарську академію. У $1956-1962$ рр. Українська сільськогосподарська академія входила до складу Української академії сільськогосподарських наук як іiї навчальна частина. На базі Української сільськогосподарської академії у серпні 1992 р. створено Украӥнський держсвний аграрний університет, якому постановою Верховної ради України від 29 липня 1994 p. № 158 надано статус національного і перейменовано в Національний аграрний університет.

Для розширення навчальної, дослідницької й інноваційної діяльності Національного аграрного університету з метою задоволення потреб агропромислової, природоохоронної та інших галузей економіки, а також ураховуючи необхідність адаптації такої діяльності до вимог міжнародних організацій дослідницьких університетів, Постановою Кабінету Міністрів України від 30 жовтня 2008 р. № 945 Національний аграрний університет перейменовано в Національний університет біоресурсів і природокористування України (НУБіП України).

Відповідно до статусу вищих навчальних закладів має IV рівень акредитації, $є$ закладом дослідницького типу, який провадить освітню, науково-дослідну, науково-інноваційну, навчальновиробничу та інформаційно-консультаційну діяльність, спрямовану на вивчення сучасних проблем науки про життя і навколишнє природне середовище, використання, відтворення та збалансований розвиток біоресурсів наземних і водних екосистем, запровадження новітніх природоохоронних агро- $\mathrm{i}$ біотехнологій, технологій відродження безпечності та родючості грунтів, енергозберігаючих агротехнологій, екологічного і правового менеджменту в сільській місцевості, здійснення моніторингу i контролю за дотриманням стандартів, якістю і безпекою сільськогосподарської продукції, продуктів ії̈ перероблення та довкілля. 
У НУБіП України є всі умови для ефективного проведення досліджень і підготовки - це -3 центри практичного навчання студентів, 7 навчально-дослідних господарств, чотири проблемні лабораторії, три науково-виробничі підрозділи, співробітники яких щорічно виконують великомасштабні дослідження (як на замовлення держави так і юридичних осіб), багатий бібліотечний фонд й фонд нормативних документів, розміщені у приміщеннях центральної наукової бібліотеки університету та іiі 5 філіалах. Сучасна матеріально-технічна база (у т. ч. упроваджені сучасні телекомунікаційні, комп'ютерні та інформаційні технології), великий досвід висококваліфікованих науково-педагогічних працівників НУБіП України покликані забезпечити підготовку фахівців з управління природокористуванням й природоохоронною діяльністю. 3 огляду на потребу суспільства та розширенням переліку спеціальностей НУБіП України ініціює ліцензування спеціальності 8.18010005 - «Екологічна політика і право».

Концепція магістерської програми підготовки професіоналів зі спеціальності 8.18010005 «Екологічна політика і право». Магістерська програма підготовки за даною спеціальністю повинна забезпечити формування у майбутніх професіоналів знань про: організаційну структуру, планування діяльності, розподіл відповідальності і практичну реалізацію, процедури, процеси й ресурси для розроблення, впровадження системи управлінських взаємин і методів, оцінки досягнутих результатів апробації, удосконалення природоохоронних управлінських рішень; досягнення цілей екологічної політики та вирішення природоресурсних, екологічних проблем різних рівнів і видів економічної діяльності - від окремого підприємства, галузі виробництва до національної, глобальної економіки; систему заходів природокористування і екологічні стратегії економічних суб'єктів, прогнозування, попередження та ліквідації наслідків екологічних порушень; систему цілей і дій органів влади та управління, спрямованих гарантій екологічної безпеки (регіону, держави) й задоволення екологічних потреб населення. Надати вміння попередження забрудненню довкілля, обов'язкової відповідності суб'єкта економічної діяльності екологічному законодавству і регламентам, вимогам, установлення екологічних показників та їх екосистемного аналізу; методології підвищення екологічної безпеки процесів виробництва і споживання, ресурсозбереження і мінімізації екологічних небезпек та ризиків. Сприяти формуванню управлінських навичок, виявляти можливі економії витрат підприємств, посилення іx конкурентноздатності, освоєння нових екологічних ринків, оптимізації якості навколишнього природного середовища з урахуванням інтересів суспільства та майбутніх поколінь, збереження і відтворення біорізноманіття та природних ресурсів геосфер; дотримання екологічного законодавства, впровадження, удосконалення системи управління охорони навколишнього природного середовища певної організації, підприємства, галузі, виду економічної діяльності для підвищення їх екологічної ефективності; керівництва схильного до екологічних пріоритетів.

Блок «Екологічна політика». Спрямований на вивчення системи екологічних концепцій, принципів, підходів, пріоритетів і напрямів діяльності, що документально оформлена та офіційно задекларована (затверджена), і яка визначає взає-мозв'язок суспільства, держави 3 навколишнім природним середовищем, формування знань і вмінь майбутніх керівників щодо розроблення екологічної політики, систем виробництва, господарювання підприємств, корпорацій, через яку демонструється схильність керівництва до екологічних пріоритетів.

Блок «Екологічне право». Спрямований на вивчення законодавчого і нормативно-правового механізму реалізації екологічної політики - закріплення екологічних прав та обов'язків громадян, екологічних інтересів суспільства, держави та юридичних осіб, розроблення алгоритмів їх реалізації і захисту, регулювання відносин у галузі використання, відновлення й охорони природних ресурсів, визначення режимів територій та об'єктів особливої охорони і забезпечення вимог екологічної безпеки в Україні.

Сфера діяльності та працевлаштування випускників. Випускники НУБіП України магістерської програми підготовки професіоналів зі спеціальності 8.18010005 - «Екологічна політика і право» зможуть забезпечити практичну, науково-дослідну та науково-педагогічну роботи у різних сферах еколого-правової діяльності для забезпечення охорони довкілля, раціонального природокористування й екологічної безпеки, а саме: системі державних органів управління природокористуванням й природоохоронною діяльністю (лінійні та функціональні органи Мінприроди України, обласні, міські та районні Ради народних депутатів і органи виконавчої влади, інспекційні служби Мінагрополітики України та підзвітних йому Державних природоресурсних агентств, санепідемслужбі МОЗ України, органи Держспоживінспекції України тощо); приємствах, організаціях, асоціаціях тощо різних форм власності, які використовують у виробничій і комерційній діяльності природні ресурси; екологічних і природоохоронних громадських об'єднаннях; середніх спеціалізованих та вищих навчальних закладах усіх рівнів акредитації, де викладаються екологічні й еколого-правові дисципліни; науководослідних і проектно-конструкторських установах різних форм власності, тематикою досліджень яких $є$ природокористування й природоохоронна діяльність.

Магістр зі спеціальності 8.18010005 «Екологічна політика і право» може займати такі посади в державному і приватному секторах: експерт з питань формування державних (регіональних) програм екологічного й соціально-економічного розвитку; фахівець-аналітик з дослідження еколого-правової в регіоні; фахівець державної еколого-правової служби; радник (консультант) з еколого-правових 
питань місцевих та обласних держадміністрацій; радник з еколого-правових питань у системі регіональних державних адміністрацій; консультант-аналітик 3 правових та екологічних питань у консалтингових організаціях; фахівець зі стратегічного управління проектами та державними програмами; експерт міжнародних, державних та регіональних еколого-правових проектів; фахівець 3 індикативного планування; консультант-аналітик в проектних організаціях i науково-дослідних інститутах; фахівець-дослідних регіональних відділень антимонопольного комітету; фахівець 3 еколого-правового моніторингу; консультант 3 питань правової та екологічної безпеки; консультант аналітик 3 питань екологічно збалансованого розвитку економіки. Таких фахівців планується розпочати підготовку у Національному університеті біоресурсів і природокористування України.

Самоаналіз діяльності НУБіП України дає змогу стверджувати про готовність ВН3 та функціонування необхідної системи заходів щодо досягнення якісно нового рівня у підготовці професіоналів за магістерською програмою зі спеціальності 8.18010005 «Екологічна політика i право» для забезпечення охорони довкілля, здоров'я населення, демократичності процесу прийняття екологічно значущих управлінських рішень, євроінтеграційних прагнень, міжнародних зобов’язань та інвестиційного клімату.

Подальші дослідження будуть спрямовані на розроблення і впровадження нових спеціалізацій для забезпечення ефективності еколого-правової підготовки $з$ урахуванням компетентнісного підходу згідно з вимогами Болонської конвенції.

\section{Література}

1. Шмандій В. М. Управління природоохоронною діяльністю: [навч. посіб.] / В. М. Шмандій, І. О. Солошич. - К. : Центр навчальної літератури, 2004. - 296 с. 2. Влавианос-Арванитис А. Биополитика. Био-окружение. Био-силлабус. Глобальная модель биоразнообразия, разработанная Интернациональным Университетом по биоокружению / А. Влавианос-Арванитис, А. Олексин. - Вып. 1. - 1993. - 10 с. 3. План выполнения решений Всемирной встречи на высшем уровне // Использование и охрана природных ресурсов в России. - 2002. - № $9-$ 10. - С. 197-181. 4. Урсул А. Д. Образование для устойчивого развития / А. Д. Урсул// Экологическое образование. - 2002. - № 1. 5. Кабінет Міністрів України; Постанова, Перелік від 27.08.2010 № 787 «Про затвердження переліку спеціальностей, за якими здійснюється підготовка фахівців у вищих навчальних закладах за освітньо-кваліфікаційними рівнями спеціаліста і магістра» // Урядовий кур'єр : офіційне видання від 22.09.2010. - № 175. 6. Національний класифікатор України - К. : Соціоінформ, 2005. -116 с. 